\title{
Juridical Study of Application of Land Based Grants for Children under Age (Minors) In Purwokerto City
}

\author{
Kusdyastuti Pratiwi ${ }^{1}$, Boma Wira Gumilar ${ }^{2}$ and Akhmad Khisni ${ }^{3}$
}

Abstract. The purpose of this study was to identify and analyze: 1) Implementation of Land Rights Application Based Grants for Children Under Age in Purwokerto. 2) Barriers to Land Rights Application Process. 3) solution or an attempt to overcome barriers that arise in the Land Rights Application Process Based Grants for Children Under Age in Purwokerto.

The approach method in this research is juridical empirical research that emphasizes the behavior of individuals or communities in connection with the law. The data used are primary and secondary data obtained through interviews and literature, while the method of data analysis was done with descriptive and qualitative analysis.

Results of the research can be concluded: 1) Implementation of Land Rights Application Based Grants for Children Under Age in Purwokerto are filing a trust, do grant agreement, made a grant deed in front of PPAT. To get the grant deed, PPAT Purwokerto provide the terms of a document that must be completed. Furthermore PPAT within a period of seven (7) days after the grant deed signed certificates are required to submit the following relevant documents to the Land Office to be registered switchover rights. 2) Barriers experienced from the Land Deed Official (PPAT) is data required SVTO not exist, it can happen PPAT delay the process to wait until the publication of SPPT of the UN office. In the Land Office, Officers from the land office convoluted in keterangannnya. The resistance of the people or the Applicant is the difficulty in the process of application for registration which is due to a lack of public knowledge about the registration of land. 3) The solution or an attempt to overcome barriers that are PPAT could short SVTO asked for a letter to the UN office, to the Land Office can provide public education related to easy and the importance of land registration. For the public to be more active in seeking information about the application process transition of land rights. Keywords: Grant; Children under Age; Certificate of Land.

\section{Introduction}

Land is a gift to mankind on earth that comes from God Almighty. From birth to death of man requires the presence of soil. Land and people can not be separated, people live and develop and carry out daily activities on the ground. Human life depends largely on the soil, because soil is a source of livelihood of human livelihood. ${ }^{4}$

The transition of land rights is a legal perbuaan aimed at transferring the rights from one party to another party. One way of transfer of land rights is through grants. Grant is a gift made by a person to another person do when they were alive and execution of the division is usually done at the time penghibah still alive. Typically the administration will not be denounced by relatives who do not accept it. Therefore, basically someone owners of wealth are entitled and free to give their property to anyone. 5

\footnotetext{
1 Students Master of Notary Law, Sultan Agung Islamic University, Semarang email dyaspratiwi.dp.dps@gmail.com

Students Master of Law, Sultan Agung Islamic University, Semarang email bomawira gumilar@yahoo.com

${ }^{3}$ Lecturer of Faculty of Law UNISSULA, Semarang

${ }^{4}$ Dyara Radhite Oryza Fea, 2018, Panduan Mengurus Tanah dan Perizinannya, Legality Yogyakarta, p. 1

${ }^{5}$ Maman Suparman, 2017, Hukum Perdata Waris, Sinar Grafika, Jakarta, p.136
} 
Before the birth of the PP 24 of 1997, for those who are subject to the Civil Code grant letter will be made in written form of the Notary Public. Letters will grant that was not created by the Notary does not have the force of law. They are subject to the customary law may be under hand, but the process must be made with the Land Office PPAT deed. ${ }^{6}$ After the birth of the PP 24 of 1997, every grant of land should be done with a PPAT deed. The transfer of land from the owners to the recipient along with the submission of a juridical (Juridische Levering), a submission must meet the formality of law, including eligibility, made through the established procedure, using documents, created by / before PPAT. ${ }^{7}$

Acquisition of land grants and the grants will transition should be registered thereto in the local Land Office, as a means of securing the land grant. Fixity, certainty, and the veracity of the information contained in the deed of the land grant is critical to the process of registration and protection of land rights for the grantor, the heirs of the grantor and grantee. Consequently, PPAT in addition to be responsible for the certainty and truth of the deed of grant, are also required to submit certificates and other warkah-warkah to the Land Office.

Registration of land essentially aims to grant certain rights to the landowner. The issuance of the certificate is giving a sense of security to landowners of their rights on the land. In order to provide legal certainty to the holders of land rights, land certificate serves as proof that strong. Land certificate is proof that behaves as a powerful means of proving the physical data and juridical data contained in it, as long as the data is in accordance with the data contained in the measurement certificate and land book.

In-law explained that each person can be the subject of the law, but according to the provisions of existing laws imperfect legal subjects means that legal subjects had only the will but not able to pour his will in legal acts. According to R. Subekti, they are minors / children under age, adults tetapii not able to do (crazy), and a woman in marriage. ${ }^{8}$

All of them are related to skills issues acted within the law. To receive a right, allowed him immature, but he must be represented by a parent or guardian. Wali here has a wealth of functions take care of children who are under their supervision as well as possible and be responsible about the losses incurred because of poor maintenance. In granting the rights, especially against objects remains inseparable from the role Deed Official Land, it means that the procedure transition requires an authentic deed made Deed Official Land, because if it is not done then the transfer of rights is void, otherwise intermediate goods move does not require authentic certificate, this can be done by direct delivery to the recipient the right or to third parties who accept the transfer of rights in the name of the assignee, as described in Article 1682 Jo Article 1687 of the Civil Code. The grant of land will also result in the transfer of rights to the land. To obtain the land rights PPAT deed then it must get through several stages of the procedure. Based on this background, lifted the title "Juridical Studies Based on the Grant Land Rights For Children Under Age In Purwokerto". This study tried to answer the problem of implementation of Land Rights Application Based Grants for Children Under Age in Purwokerto and Obstacles and solutions in the Application Process Rights to Land Based Grants for Children Under Age in Purwokerto.

\section{Research Methods}

\footnotetext{
${ }^{6}$ Effendi Perangin, 1990, Mencegah Sengketa Tanah, cetakan ke-2, Rajawali, Jakarta, p.46

7 Abdul Kadir Muhammad, 1994, Hukum Harta Kekayaan, Citra Aditya Bakti, Bandung, p. 55

8 R. Subekti, 1994, Pokok-pokok Hukum Perdata, Internusa, Bandung, p.341
} 
The method used in this research is juridical empirical. Juridical empirical research that focuses on the behavior of individuals or communities in connection with the law. ${ }^{9}$ Specification of the research is descriptive. Primary data were collected by interview. Type of interview used in this study using a free guided interview, is a combination of free and guided interview. ${ }^{10}$ Secondary data is data obtained from a review of the literature or the review of the literature or library materials related to the problem or research materials that are often referred to legal materials. ${ }^{11}$ Analysis of the data used in this research is the analysis of qualitative data that have been obtained from field studies and literature will be collected and systematically categorized and then analyzed qualitatively in order to obtain an overview and understanding of the systematic and comprehensive to address the problems examined.

\section{Results and Discussion}

\subsection{Implementation of Land Rights Application Based Grants for Children Under Age in Purwokerto}

The process of petition Land Tenure transition grant for minors in Purwokerto are as follows: ${ }^{12}$

- Because the subject of the transfer of rights to the land are children who are still minors and have not been able to carry out a legal action itself, it should diwaliki guardian or person responsible for the child. Filing the form of a letter of guardianship guardianship by the trustee to the subject of the grant of the juveniles in the management of the transition ownership of the land grant, from the signing of the deed of grant to the registration office to the Land. The trust must be known by the local sub-district and village heads.

- After doing the filing parties must trust the grant agreement, the form of a Grant Agreement by the Grantee Grant-making. In the case of the making of this grant agreement must be approved by all parties interested / concerned, as witnessed by the local Village devices.

- After making the soil Grant Agreement, the parties shall make a Deed of Grant in front of PPAT (Land Deed Official) in Purwokerto. To get the grant deed, PPAT Purwokerto provide requirements document that must be completed are: Grant Agreement Letter; ID-card (KTP) of grant providers (husband or wife); ID-cards of all the heirs prospective grantors; The grant Marriage Certificate; Family card grantor; Certificate of Status of Land created the village chief or local sub-district or proof of land ownership (original certificates for checking); SPPT and last year's UN STTS; Other conditions required (a power of attorney to grant); ID-card of Grantees (guardians are authorized); Letter of consent from the prospective heirs of the grantor.

Before the applicant sign the deed of grant in the presence of PPAT, first PPAT do examination or check the certificate at the Land Office. This is justified by Ms. Ranni, $^{13}$ that before executing a deed regarding the transfer of land rights or

\footnotetext{
${ }^{9}$ Soerjono Soekanto dan Sri Mamadji, 2009, Penelitian Hukum Normatif: Suatu Tinjauan Singkat, RajaGrafindo Persada, Jakarta, p.1

${ }^{10}$ Ibid, p. 84

11 Mukti Fajar dan Yulianto, 2010, Dualisme Penelitian Hukum Normatif dan Empiris, Pustaka Pelajar, Yogyakarta, p. 156

${ }^{12}$ Interview with Laila Hasyim, SH, MH, PPAT in Purwokerto, June 29, 2019

${ }^{13}$ Interview with Ranni Risananti, Kasubseksi Registration Rights Banyumas District Land Office, July 5th, 2019
} 
imposition, PPAT shall first make checks / checks at the Land Office on the suitability of land certificates in question dnegna list of books land in the Land Office by showing originalcertificate. If the certificate is appropriate / suitable to register in the office of Land, then Head of the Land Office or appointed official stamped or written with the words: "It has been checked and in accordance with the list in the office of the Land" on page changes the original certificate, later initialed and dated checks. The reason of the existence of these provisions is in order to be immediately known by PPAT and other concerned parties if there is a discrepancy between the data written on the certificate with the existing data dibuku disimpah land in the Land Office.

If the certificate is not a document issued by the Land Office, then on the cover and all the pages of the certificate is stamped or written with the words "This certificate is not issued by the District Land Office Banyumas" then initialed. Once the certificate has been checked, then returned to the PPAT is concerned, the return of the certificate is performed on the same day to day checks.

Furthermore PPAT within a period of seven (7) days after the grant deed signedrequired the following deed conveying the relevant documents to the Land Office to be registered switchover rights. Once all the paperwork is complete, Grant Deed was issued that had been made and was read in front of the party, and was attended by the witness which all heirs of the grantor and the witness of the local Village devices.

- Furthermore, namely the transition Registration of Land Ownership Rights to Land Office Banyumas.

Applicant with a document came to Loket II requirements. Counters II officers received the document, check the completeness, document, when the full document of attendant application data in the computer, then print STTD (Receipt Document) and SPS (Warrant Deposit) and giving to the Applicant. Admission requirements Transition of Land Ownership Rights to the Land Office Banyumas namely:

- Letter from Navan Town PPAT deed that has made a grant of land.

- Application letter.

- The power of attorney, if the application is authorized.

- deed of grant

- Identity of the rights holder, assignee or agent (copy of ID and valid KK and legalized by the competent authorities).

- Original certificate.

- Proof of payment of SSB BPHTB.

- Final proof of payment of SSP Pph (for vertical Pph if the grant is not required).

- UN SPPT current year

- Assignment permit, if: Transfer of Land Rights or Hak Upper Flats are in sertipikatnya included a sign stating that these rights may only be transferred if it has obtained permission from the competent authority; The transfer of land use rights on the state.

- Potential beneficiaries affidavit stating: That is concerned with the transfer is not a land-rights holders who exceed the maximum provision of land ownership under the provisions of the legislation in force; That is concerned with the transfer is not an absentee land-rights holders in accordance with the provisions of applicable law; That is concerned to realize that if the declaration referred not true, then the excess soil or absentee land that became the object of reform; That the person concerned is willing to bear all the legal consequences, if the declaration referred not true. 
Applicant pay the registration fee to the treasurer in Loket III and receive a receipt of payment. STTD Officer Counters II handed to the applicant and subsequently handed over documents to the executive officer of the Transitional imposition of Rights. Preparing land book records clerk land book and handed the land to the executive officer. The executive officer corrects the document and make a record transfer of rights in land books and certificates. The executive officer Kasubsi the documents to PPT and PPAT.

Headsub-division of PPH and PPAT: Correct and validate the documents, if not properly returned to the executive officer for repair; Initials transition records on land books and certificates; The documents to the Head of HT and PT.

Head Division of HT and PT correct and validate the documents: If not properly returned to the executive officer for repair; Initials record transfer of rights in land books and certificates; The documents to the Head Office.

Head office: Correct and validate the documents; If not properly returned to the executive officer for repair; Initials record transfer of rights in land books and certificates; The documents to the executive officer.

The executive officer of HT and PT: Provide office stamp; Restoring the land to the book archives officer of the land book; Submit documents to the clerk warkah warkah archives; Handed certificates to the officers Loket IV.

Officer Counters IV: Print proof of delivery of the product; Surrender the certificate to the applicant.

After all the documents are met and declared its truth by the clerk of the Land Office Land Office subsequently publishes certificates Evidence of Property Rights on behalf of the holders of Rights that is the subject of the grant minors. ${ }^{14}$ On the registration procedure from beginning to end / finished by the deposit certificate to the name that has been reversed on behalf of the applicant required a period of about 3-4 weeks. About registration of transfer of rights in land books and certificate as follows:

- Name of rights holders long in the land book crossed out with black ink and stamped initials Head of the Land Office or appointed official.

- The name or names of the holders of the rights newly written pages and columns in the books of the soil with the stamped date of record and substantiality of the portion of each holder of rights in terms assignee some people and substantiality of the portion is determined, and then signed by the head of the Office of land or officials appointed and official stamp of the Land Office.

- Mentioned in letters $a$ and $b$ are also carried out on the relevant right certificates and lists containing the names of other common long rights holder.

- Numbers and other identity rights of the transferred land cut from the rights holder old name and number and the identity of the recipient's name written on the list of rights.

After process The completed, a certificate that has been renamed with the name of the new rights holder of the certificate submitted to rights holders or proxy.

\subsection{Obstacles in Land Rights Application Process Based Grants for Children Under Age in Purwokerto}

Writers find bottlenecks in land-related grants for children who are still minors in Purwokerto, namely:

- Land Deed Official (PPAT)

\footnotetext{
${ }^{14}$ Interview with Agus Priyanto, headsud-division of Land Rights and Land Registration District Land Office Banyumas, July 5th, 2019
} 
Factors that are usually of PPAT was in the early years of frequent office land and building tax has not been published SPPT for the current year, but when it comes applicant to transfer rights to the land, then the data SVTO required is not there, it can happen PPAT delay the process the SPPT wait until the publication of the UN office. ${ }^{15}$

- Land office

In providing information or explanations related to the implementation of the transition process or plot of land rights for a grant to minors, there are Officers of the land office convoluted in keterangannnya, so sometimes cause people difficulty to choose to use a legal representative. Besides long file until the Land Office but until the appointed time has not been completed, and only after the applicant asked the new officers obtained answers there are still shortcomings that must be met by the applicant.

- Community or Applicant

Communities in Purwokerto not all highly educated. Therefore the application process based grant land rights to children under the age they still find it difficult to meet all the requirements. This is due to the lack of public knowledge about the registration of land. In addition, there is the assumption most people that the land registration process requires high costs, long processing time and the process is long-winded.

\subsection{Solutions or efforts to overcome barriers that arise in the Land Rights Application Process Based Grants for Children Under Age in Purwokerto}

Against some of the obstacles in the implementation of the above application for land rights can be sought a solution or an attempt to overcome these barriers include:

- To PPAT

In case of trouble earlier in the year have not been published SPPT by the UN office, then PPAT can take the road to require a statement SVTO to the UN office, because the issue SVTO is important in terms of calculating the amount of tax of right receiving on land and buildings that should be paid by the applicant, where it is is one of the requirements that must be met applicant for registration of transfers of property.

- For Land Office

Land Office should look back on the registration of the land itself and asa-asa and penyelenggarannnya goal. As for its principles are simple, safe, affordable, advanced and open. With the existence of those principles, it can give meaning, purpose to the community is no longer so easily duped by those who are not responsible to be detrimental to the community itself. Because with understands and knows the community can take care of the land registration smoothly, properly and provide the benefit of society itself. Land Office can also provide public education related to easy and the importance of land registration. This socialization will greatly help the public, because the public became aware of the issue of land registration.

- For the community

To the problem that there are still people who feel difficulty in the application process transition their land rights, the public should be more active and open mind again in the search for information as much as possible, before the application process transition of land rights. That information can be obtained from the office

\footnotetext{
${ }^{15}$ Interview with Ali Akbar, SH., M.KN, Notary PPAT in Purwokerto, July 5th, 2019
} 
held socialization of Land, internet, books, and other social media. This is done to prevent its share participated parties who are not responsible to the detriment of society itself. If people have got enough knowledge about the land, especially land rights and the transfer of land registration, then the assumption that registration requires a high cost and long-winded affair will be reduced. Communities will also realize that the cost will be higher if the land in question there are problems / disputes, if it happens like it needed a higher cost and turnaround time is also longer.

\section{Closing}

\subsection{Conclution}

Based on the research that the authors have described above, the conclusions of this research are:

- Implementation of Land Rights Application Based Grants for Children Under Age in Purwokerto, namely pengajuan guardianship did grant agreement, made a grant deed in front of PPAT. Furthermore PPAT within a period of seven (7) days after the grant deed signed certificates are required to submit the following relevant documents to the Land Office to be registered switchover rights. Applicant with the document requirements come into Loket II, Officer Counters II received the document, check the completeness, document, when the full document clerk mengentri application data in the computer, then print STTD (Receipt Document) and SPS (Warrant Deposit) and giving to Applicant. Admission requirements Transitional Land Tenure to Land Office Banyumas ie Letter of PPAT Purwokerto already made a deed of grant of the land, Application Letter, Power of attorney, if the application is authorized, deed of grant, Identity of the rights holder, assignee or agent (photocopy ID-Card (KTP) and KK valid and legalized by the competent authorities), First Certificate. BPHTB SSB payment receipt, proof of payment of SSP Pph Final (for vertical Pph if grant is not required), the UN SPPT current year. Then the land officer correct and validate the documents, after all the documents are met and declared its truth by the clerk of the Land Office Land Office subsequently publishes certificates Evidence of Property Rights on behalf of the holders of Rights that is the subject of the grant minors.

- Obstacles in Land Rights Application Process Based Grants for Children Under Age in Purwokerto of Land Deed Official (PPAT) is data required SVTO not exist, it can happen PPAT delay the process to wait until the publication of SPPT of the UN office. In the Land Office. Officers from less land office can be fast in the ministry. The resistance of the people or the Applicant is the difficulty in the process of application for registration which is due to a lack of public knowledge about the registration of land.

- Solutions or efforts to overcome barriers that arise in the Land Rights Application Process Based Grants for Children Under Age in Purwokerto, namely to PPAT could short SVTO asked for a letter to the UN office. For the Land Office can provide public education related to easy and the importance of land registration. This socialization will greatly help the public, because the public became aware of the issue of land registration. For the public to be more active in seeking as much information before making the application process transition of land rights.

\subsection{Suggestion}

Based on the above conclusions, suggestions authors in this study are: 
- Given the legal acts involving minors requiring guardianship has not been well understood by citizens, the need for dissemination of government at both the village and the Land Office.

- For people who have rights to the land acquired through a grant should make efforts to shift proprietary rights over the land in accordance with the procedures and requirements have been determined, although there Letter $\mathrm{D}$ or $\mathrm{C}$ village is also a proof of ownership but legal force would be stronger if The Make a deed of grant and continued into the certificate of land rights.

\section{Bibliography}

\section{Book}

[1] Abdul Kadir Muhammad, 1994, Hukum Harta Kekayaan, Cetakan I, Citra Aditya Bakti, Bandung

[2] Abintoro Prakoso, 2016, Hukum Perlindungan Anak, LaksBang PRESSindo, Yogyakarta

[3] Achmad Ali, 2009, Menguak Teori (Legal Theory) dan Teori Peradilan (Judicialprudence) termasuk Interprestasi Undang-Undang (Legisprudence), Predana Media Group, Jakarta

[4] Adrian Sutedi, 2018, Peralihan Hak Atas Tanah dan Pendaftarannya, cet.9 Sinar Grafika, Jakarta

[5] Chainur Arrasjid, 2008, Dasar-Dasar IImu Hukum, Sinar Grafika, Jakarta

[6] Chairuman Pasaribu dan Suhrawadi K Lubis, 1996, Hukum Perjanjian Dalam Islam, Cetakan Kedua, Sinar Grafika, Jakarta

[7] Dyara Radhite Oryza Fea, 2018, Panduan Mengurus Tanah dan Perizinannya, Legality Yogyakarta.

[8] H. Salim HS, H. Abdulah, dan Wiwiek Wahyuningsih, 2014, Perancangan Kontrak dan Memorandum of Understanding (MoU), Sinar Grafika, Jakarta

[9] Herlien Budiono, B, 2011, Ajaran Umum Hukum Perjanjian dan Penerapannya di Bidang Kenotariatan, Penerbit PT. Citra Aditya Bakti, Bandung

[10]Maman Suparman, 2017, Hukum Perdata Waris, Sinar Grafika, Jakarta

[11]Munir Fuady, 2014, Konsep Hukum Perdata, Raja Grafindo Persada, Jakarta

[12]R. Subekti, 1994, Pokok-pokok Hukum Perdata, Internusa, Bandung

[13]Soerjono Soekanto dan Sri Mamuji, 2003, Penelitian Hukum Normatif Suatu Tinjauan Singkat, Raja Grafindo Persada, Jakarta

[14]Supriadi, 2010, Hukum Agraria, Cetakan Keempat, Sinar Grafika, Jakarta

\section{Legislation}

[1] Act 5 of 1960 On the Basic Regulation Agrarian

[2] Act No. 24 of 1997 on Land Registration

[3] Law of the Republic of Indonesia Number 35 of 2014 on the Amendment of the Law of the Republic of Indonesia Number 23 of 2002 on Child Protection

[4] Government Regulation No. 20 of 2015 on Land Agency

[5] Indonesian Government Regulation No. 24 of 2016 on Amendment of Government Regulation No. 37 of 1998 About the Position Rules PPAT 